\title{
The Curious Case of Rule 165 of the Rules of Procedure and Evidence: The Effect of Control Exercised by the Assembly of States Parties over the International Criminal Court
}

\author{
Kritika Sharma \\ PhD Candidate, Leiden University, The Netherlands; ICJ Judicial \\ Fellow 2017-2018 \\ k.sharma.4@law.leidenuniv.nl
}

\begin{abstract}
This article analyses the relationship between the International Criminal Court (ICC) and its international judicial governance institution, the Assembly of States Parties (ASP). It does this in particular respect to the legislative function of the ASP in relation to the Rules of Procedure and Evidence. With this objective, the article focuses on the provisional amendment to Rule 165 of the Rules of Procedure and Evidence by the Court, as well as the AsP's response to this. This article analyses the process through which the ASP assesses this provisional amendment and determines whether, in practice, the present legal and institutional framework allows for an overlap of mandates between the AsP and ICC.
\end{abstract}

\section{Keywords}

accountability - governance - judicial independence - Assembly of States Parties (ASP) - International Criminal Court (ICC) - Rules of Procedure and Evidence (RPE)

With heightened focus and criticism on the work of the International Criminal Court (ICC) being the focus at present, this article attempts at contributing to, 
as well as broadening this evaluative debate to include the work of the ASP and its relationship with the ICC. The larger objective underlining this article is to highlight the potential impact of the ASP over the work of the ICC, however the scope of this article is limited to the legislative prerogative of the ASP in relation to the RPE of the ICC. In pursuit of this objective, the modus operendi of this article is to analyse the adoption in 2016 of provisional Rule 165 to the RPE by the Court in accordance with Article 51(3) of the Rome Statute ${ }^{1}$ and the response of the ASP to this, or perhaps better framed as its decision 'not to decide. ${ }^{2}$

Article 51(3) discussed in greater detail in this article, is the only exception to the legislative prerogative of the ASP, allowing the judges to adopt provisional amendments to the RPE to deal with exigent circumstances not catered for by the RPE as they stand. These amendments are designed to be provisional and therefore are required to be adopted, amended or rejected by the ASP at its next session. The Court exercised this power for the first time on 10 February 2016, when acting in plenary, ${ }^{3}$ by adopting provisional Rule $165 .{ }^{4}$ The ASP however chose to take no decision.

This article analyses the ASP's decision 'not to decide' in light of the legislative framework adopted by the States for amending the RPE. This article also analyses the repercussions of this decision which are in context of the particularities of the provisional amendment which disapplies several provisions of the RPE to 'Article 70' or 'offences against the administration of justice' proceedings. The resultant provision arguably raises several questions relating to

1 The views expressed in this article are of the author alone and are expressed in this personal capacity. ICc, Report on the Adoption by the Judges of Provisional Amendments to Rule 165 of the Rules of Procedure and Evidence, 29 February 2016.

2 The ASP is yet to adopt, amend or reject the provisional amendment to Rule 165 . There is a reference to this in the 2018 Report of the Working Group on Amendments, albeit slightly misplaced and lacking any definitive solution to the problem; see ASP, Report of the Working Group on Amendments (2018), ICC-ASP/17/35, at 5. The representative of Slovakia also mentioned this is in his address to the 17 Session of the ASP during the General Debate, where he warned the Assembly of the "dangerous legal uncertainty" that the inaction of the ASP on this question has resulted in; see Statement by H. E. Roman Bužek, Ambassador Plenipotentiary and Extraordinary of the Slovak Republic to the Kingdom of the Netherlands to the Seventeenth Session of the Assembly of States Parties to the Rome Statute, The Hague, 5 December 2018.

3 Regulations of the Court, ICC, Regulation 2.

4 ICC Report, supra note 1, at 1. 
rights of the defence and also reduces the number of judges to one unless there is a joinder of charges (see Table 1). ${ }^{5}$ Based on the AsP's decision not to decide, the law applicable to these proceedings is now uncertain and in a state of flux.

Evaluation of this unique situation is through a three-step approach. First, is an analysis of the unique legal framework for amending the RPE, including the power conferred on the Court to adopt provisional rules under Article 51(3) and the scope of the AsP's powers in relation to such provisional rules adopted by the Court including whether the manner in which the ASP acted in relation to the adopted provisional rule, results in a de facto review of the Court's decision. Second, this article attempts at tracing the source for possible overreach by the ASP determining whether this can be attributed to individual transgression by States Parties or legal lacunae. Third, this article explores possible mechanisms and safeguards to address such overreach, if any. Aiming at an analysis of the legislative prerogative of the ASP in practice, this article evaluates the lex lata governing the relationship between the ASP and the ICC in view of the issues arising under Article 51(3). This evaluation is positioned towards lex ferenda, in terms of ensuring the proper functioning of the entire institutional machinery that supports the independent judicial function at the Court.

This section analyses the legislative role of the ASP in relation to the Court. In particular it highlights the unique decision of the States Parties to allot exclusive legislative prerogative to the ASP in relation to the Rule of Procedure (RPE), albeit with an exception for exigent circumstances. It then analyses the legal framework in relation to the adoption of provisional rules by the Court under Article 51(3), and the powers of the ASP in relation to these provisional rules. This analysis is in the context of the recent adoption of provisional Rule 165 by the Court, and the subsequent response of the ASP. ${ }^{6}$

5 This table reflects the changes incorporated into Rule 165 through the provisional amendment adopted by the judges as documented in their Report. These changes are shown in italics. See ICc Report, supra note 1.

6 See ICc Report, supra note 1. 


\section{Original Rule}

1. The Prosecutor may initiate and conduct investigations with respect to the offences defined in article 70 on his or her own initiative, on the basis of information communicated by a Chamber or any reliable source. 2. Articles 53 and 59, and any rules thereunder, shall not apply. 3. For purposes of article 61 , the Pre-Trial Chamber may make any of the determinations set forth in that article on the basis of written submissions, without a hearing, unless the interests of justice otherwise require.

4. A Trial Chamber may, as appropriate and taking into account the rights of the defence, direct that there be joinder of charges under article 70 with charges under articles 5 to 8 .

\section{Provisionally Amended Rule}

1. The Prosecutor may initiate and conduct investigations with respect to the offences defined in article 70 on his or her own initiative, on the basis of information communicated by a Chamber or any reliable source.

2. Articles 39(2)(b), 53, 57(2), 59, 76(2) and $82(1)(d)$ and any rules thereunder, shall not apply. A Chamber composed of one judge from the Pre-Trial Division shall exercise the functions and powers of the Pre-Trial Chamber from the moment of receipt of an application under article 58. A Chamber composed of one judge shall exercise the functions and powers of the Trial Chamber, and a panel of three judges shall decide appeals. The procedures for constitution of Chambers and the panel of three judges shall be established in the Regulations. 3. For purposes of article 61, the Pre-Trial Chamber, as constituted under sub-rule 2, may make any of the determinations set forth in that article on the basis of written submissions, without a hearing, unless the interests of justice otherwise require.

4. The Trial Chamber seized of the case from which the article 70 proceedings originate may, as appropriate and taking into account the rights of the defence, direct that there be joinder of charges under article 70 with charges in the originating case. Where the Trial Chamber directs joinder of charges, the Trial Chamber seized of the originating case shall also be seized of the article 70 charge(s). Unless there is such a joinder, a case concerning charges under article 70 must be tried by a Trial Chamber composed of one judge. 

Procedure and Evidence (RPE)

States Parties quite clearly intended to confer primary authority in relation to 'rule making' to the ASP. ${ }^{7}$ This is evidenced through the regime adopted by the States, granting complete legislative prerogative to the ASP, including in relation to the RPE. ${ }^{8}$ This is juxtaposed to the practice followed by other international courts and tribunals where the judges draft their own rules. ${ }^{9}$ As far as the RPE are concerned, the desire of the States that these be determined by the States themselves through a process similar to the one followed for the adoption of the Statute is evident from Article 51(1) which reads as 'Rules of Procedure and Evidence shall enter into force upon adoption by a two-thirds majority of the members of the Assembly of States Parties.' ${ }^{10}$ The rationale underlining this could arguably be the fact, that this process entailed placing these proposed rules under detailed discussion and meticulous debate before the States, unlike in the case of ad hoc Tribunals. ${ }^{11}$

Initially, as indicated in the ILC Commentary on the Draft Statute, ${ }^{12}$ there were divergent views on the issue of whether the RPE should in fact be elaborated by the Court itself or by States. ${ }^{13}$ The emergent view appeared to be in

B. Broomhall, 'Article $5^{1}$ Rules of Procedure and Evidence', in O. Triffterer and K. Ambos (eds.), Commentary on the Rome Statute of the International Criminal Court, Observers' Notes, Article by Article, Third Edition (C.H. Beck, Hart, Nomos, Munich, 2016) at 1333-36. W. Schabas, The International Criminal Court: A Commentary on the Rome Statute (Oxford University Press, Oxford, 2016) at 813.

9 Broomhall, supra note 7 at 1349; R.S. Lee and Håkan Friman, The International Criminal Court, Elements of Crime and Rules of Procedure and Evidence (Transitional Publishers, Ardsley, NY, 2001) at 236; see Article 15 of the Statute for the International Criminal Tribunal for the Former Yugoslavia 1993; Article 14 of the Statute for the International Criminal Tribunal for Rwanda, 1994; The Kosovo Specialist Chambers Judges adopted the Rules of Procedure and Evidence for the Court on 17 March 2017, sitting in plenary, see for e.g., Judgment on the Referral of the Rules of Procedure and Evidence to the Specialist Chamber of the Constitutional Court, Pursuant to Article 19(5) of Law No. 05/L-03 on Specialist Chambers and Specialist prosecutor's Office, 26 April 2017, at 1.

101998 Rome Statute of the International Criminal Court, 2187 UNTs, Article $51(1)$.

11 F. Guariglia, 'The Rules of Procedure and Evidence for the International Criminal Court: A New Development in International Adjudication of Individual Criminal Responsibility', in A. Cassese, P. Gaeta, J.R.W.D. Jones (eds.), The Rome Statute of the International Criminal Court, A Commentary (Oxford University Press, Oxford, New York, 2002) at 1121.

12 See Draft Statute for an International Criminal Court with Commentaries, 1994 YILC, Vol.II, (Part Two), at 36.

13 See S.A. Fernández de Gurmendi, 'Elaboration of the Rules of Procedure and Evidence', in Lee and Friman (eds.), supra note 9 at $236-237$. 
favour of striking a balance between the advocates of judge-made rules and those who preferred greater State control over the rules of the Court. This was by catering for a certain degree of State involvement in the form of approval. ${ }^{14}$ However during the process of drafting the Rome Statute and supplementary documents thereto, the voices in favour of the RPE being drafted by the judges were overshadowed by the prevalent desire of States to exercise control over the procedural framework of the Court. As apparent from the decision to task the Preparatory Commission with the elaboration of the Draft Rules and consequent adoption by States Parties, the concept of judge-made rules, subject to subsequent State approval was abandoned. There nevertheless is an element of this thought process in Article 51(3) which allows the judges to provisionally amend the RPE in exigent circumstances.

It has been argued that dissatisfaction with judge-made rules weighed into the decision to allot the ASP principal authority over the RPE. ${ }^{15}$ This is interesting since criticism of the concept of judge-made rules, based partly on the principle of legality, ${ }^{16}$ is usually reinforced with the example of the repeated amendments to the RPE by the judges at the Ad Hoc Tribunals. However, at the point when the States rejected the idea of judge made rules, in the context of the ICC, the Ad Hoc Tribunals had only recently been established. By the time the Preparatory Commission elaborated the Draft RPE for the ICC, the RPE of the ICTY had been revised 14 times in five years. ${ }^{17}$ These amendments might have provided critics of the 'judge legislator model' added impetus for rejecting this model, citing lack of procedural certainty. Though relatively high in number, such amendments are insufficient as a solitary basis for such criticism.

While analysing the decision not to grant judges the power to adopt rules, it is worth taking into consideration the power limiting function of the RPE and rules governing criminal jurisdiction in general. These rules essentially regulate and extrapolate the manner in which the powers and functions elucidated under the Rome Statute are to be exercised. This makes it fundamental to distinguish between those being governed by these rules, from those who create

\footnotetext{
$14 \quad$ Ibid., at 237.

15 Schabas, Commentary on the Rome Statute, supra note 8, at 813.

16 Ibid.

17 In relation to amendments to the RPE at the ICTY, see S.A. Fernández de Gurmendi and H. Friman, 'The Rules of procedure and Evidence of the International Criminal Court', 3 Yearbook of International Humanitarian Law (2000) 291.
} 
them. ${ }^{18}$ Prima facie the decision of the States appears to have both 'control', and 'separation of power' related underpinnings. Professor Broomhall is a proponent of the latter, stating that this decision was an indication of the desire of the States to draw a clear distinction between adjudicator and legislator. ${ }^{19}$ Professor Schabas subscribes to the former, describing this as an issue of control, through which the States explicitly express the need to exercise control over the functioning of the Court and the law that binds its operations. ${ }^{20}$

While the concept of separation between adjudicator and legislator warrants merit not only at the platform of the ICC in particular, but as a fundamental principle underlining dispensation of justice, ${ }^{21}$ the issue of control nonetheless appears to have been a prominent factor in the deliberations of States. Therefore, the decision to control all legislative matters including the RPE of the Court, might have been to control the law that governs the exercise of jurisdiction of the Court to which States Parties, agreed to bind themselves to, under certain circumstances. This removes the possibility of judges creating rules that result in States being subject to a legislative regime that they did not explicitly consent to, thus vitiating the consent that underlined the Court's jurisdiction. It has also been referred to as an attempt to shield the procedural framework of the Court from short term or case based changes, as well as changes steered by political aspirations. ${ }^{22}$ Therefore, there appears to have been a deliberate decision taken by States to ensure a certain degree of control over the jurisdictional regime that they agreed to submit themselves to, whilst simultaneously rejecting the 'judge legislator' model.

\subsubsection{Amendments to the Rules of Procedure and Evidence (RPE)}

As a corollary to its function as legislator to the Court, the ASP may also amend the RPE as envisaged under Article 51(2). ${ }^{23}$ This is of particular significance since the voting procedure is different and does not require ratification as a precursor to application. Amendments to the RPE thus apply uniformly to all

18 See for e.g., problems that arose on amendment of Rule 15 by the ICTY judges in 1999, Guariglia, supra note 11, at 1117 .

19 Broomhall, supra note 7 , at 1044.

20 Schabas, Commentary on the Rome Statute, supra note 8, at 813.

21 Separation of judicial and legislative power has been referred to as 'one of the pillars of "enlightenment of legal thought", see Charles de Secondat, baron de Montesquieu, The Spirit of the Laws (Cambridge University Press, Cambridge, 1989) at 157.

See P. Ambach, 'The "Lessons Learnt" process at the International Criminal Court', (2016) 12 Zeitschrift für Internationale Strafrechtsdogmatik 854-867, at 857 .

23 ILC 1994, Final Report at 25 (para. 75); see also Guariglia, supra note 11, at 1113. 
States Parties. ${ }^{24}$ The ASP has so far on five occasions ${ }^{25}$ adopted amendments to the RPE in accordance with Article $51(2) .{ }^{26}$ It is important to note that Article $51(2)$ differentiates between the power to initiate amendments and actual power to adopt such proposed amendments. ${ }^{27}$

The power to initiate the decision-making machinery envisaged under Article 51(2) has been conferred to States Parties, the Prosecutor, as well as Judges, acting in absolute majority. According to the Regulations of the Court, which incidentally have been adopted by the Court itself, the process for such proposal varies based on the party submitting it. ${ }^{28}$ Proposals for amendments by judges must be submitted to the Advisory Committee on Legal Texts (ACLT), ${ }^{29}$ followed by a report or recommendation by the Committee to the ASP. This is not necessary for proposals by the Prosecutor, which may be submitted to the ACLT for a report. ${ }^{30}$ While the Presidency ${ }^{31}$ acting under Article $51(3)$ which is discussed in greater detail in the next section, is not required to submit a proposal for amendment to the ACLT and can directly submit the same to the judges sitting in plenary, practice indicates that on the only occasion where the judges have taken recourse to this provision, the proposal for the same was in fact placed under consideration before the ACLT. ${ }^{32} \mathrm{Howev}$ er while that amendment in particular was provisionally adopted under Article 51(3), it was referred to the ACLT by the Working Group on Lessons Learnt. ${ }^{33}$

The Proposals for amendments to the RPE are to be sent to the President of the ASP Bureau, and are then translated and transmitted to the States Parties. ${ }^{34}$ Article 51(4) can further be seen as laying down limitations concerning such

24 Rome Statute, Article 112(7)

25 ASP, Amendments to Rule 4 of the Rules of Procedure and Evidence, (2011), ICC-ASP/10/ Res.1; ASP, Amendment of the Rules of Procedure and Evidence, (2013), ICC-ASP/11/Res.2; ICC-ASP/12/Res.7; ASP, Report of the Working Group on Amendments, (2016), ICC-ASP/15/24; ASP, Report of the Working Group on Amendments (2018), ICC-ASP/17/35.

26 Rome Statute, Article 51(2).

27 Ibid.

28 Schabas, Commentary on the Rome Statute, supra note 8 at 815 .

29 Regulations of the Court, ICC, Regulations 2, 4, and 5.

3o Regulations of the Court, ICC, Regulation 5(1).

31 Rules of Procedure and Evidence ICc, Rule 4 bis.

32 Ambach, supra note 22, at 865-866; (citing the Report of the Study Group on Governance: Cluster I: Expediting the Criminal Process: Progress Report on Clusters A, B, C, and E, ICC-ASP/14/30, Annex II).

Ibid.

34 Rome Statute, Article 51(2); Rules of Procedure and Evidence ICC, Rule 3; Rules of Procedure of the Assembly of States Parties, ICC-ASP/1/3, Rule 73; see also Schabas, Commentary on the Rome Statute, supra note 8 , at 814 . 
amendments, specifying that the amendments so envisaged and proposed, need to be consistent with the Rome Statute itself, and regulating the retroactive application thereof. ${ }^{35}$ These amendments must be adopted by two-thirds majority of the members of the ASP. ${ }^{36}$ In practice however the ASP prefers to adopt amendments through consensus.

The ASP through a resolution adopted by it in 2009, established the Working Group on Amendments (WGA) ${ }^{37}$ for the purpose of 'identifying' amendments to the Rome Statute as well as the RPE. ${ }^{38}$ In relation to the RPE, the ASP refers proposed amendments in accordance with Article 51,39 to the WGA, whose mandate ${ }^{40}$ under its terms of reference involves detailed consideration of such amendments, and subsequently making positive recommendations ${ }^{41}$ to the ASP on whether it should adopt the proposed amendment. ${ }^{42}$ Therefore the WGA carries out a 'preliminary examination' of such proposed amendments ${ }^{43}$ through detailed discussion and creates the basis for consensus for its eventual adoption at the ASP.

On the other hand, because of the relatively informal structure of subsidiary bodies of the ASP and working groups in general, it brings with it a margin of uncertainty as regards the process. The WGA has at times referred to an 'expert meetings format' for which there are no formal guidelines emphasizing particular requirements concerning the composition of delegations represented at the WGA. ${ }^{44}$ Thus, recommendations by this body can prove to be especially complicated for the ASP given the nature of the Court and its jurisdiction and the fact that a high degree of weight seems to be given to the recommendations and reports ${ }^{45}$ of the WGA.

\footnotetext{
35 Rome Statute, Article 51(4).

$36 \quad$ Rules of Procedure of the ASP, Rule 73.

37 Rome Statute, Article 112(4); see also terms of reference for the WGA, Resolution ICC-ASP/11/Res.8, at 11.

38 ICC, Review Conference, (2009), ICC-ASP/8/Res.6, 2009, at 2.

39 Rome Statute, Article 51.

40 The ASP in an annex to its resolution, invited the WGA to continue its consideration of all amendment proposals', see ASP, Strengthening the International Criminal Court and the Assembly of States Parties (2015) ICC-ASP/14/Res.4, at 18.

41 Ibid., para. 19.

42 ASP, Strengthening of the International Criminal Court and the Assembly of States Parties, (2012) ICC-ASP/11/Res. 8, at 12.

43 Ibid., at 11 .

44 Regular meetings of the Working Group appear to be open to all delegations.

45 Schabas, Commentary on the Rome Statute, supra note 8, at 1446.
} 
The Working Group has the ability to potentially effectuate change in the legislative structure of the Court. Countries that have been involved in situations under the jurisdiction of the Court actively participate in WGA meetings, as they are entitled to as States Parties. This could seemingly play a role, however slight, in the recommendations, perhaps highlighting the possibility for a conflict of interest.

Irrespective, it is important to note that the WGA merely makes recommendations to the ASP, and eventually it is the ASP in plenary, that decides whether or not to adopt the amendments. The WGA thus acts as a precursory check on whether or not the amendment carries with it adequate State support. After presentation of the report by the Chair of the WGA, the President of the ASP at the time of adopting resolutions and reports asks the ASP if there is consensus, and if no objections are raised, declares that the report or resolution is 'adopted without a vote'.

Therefore, there appears to be an elaborate and multi-layered structure for the consideration of amendments to the RPE. This includes several platforms for dialogue between the stakeholders of the ICC, including both members of the Court and the States Parties despite the absence of any legal requirement for the States to consult the Court before considering and adopting amendments to the RPE. ${ }^{46}$

2.1.2 Provisional Amendments to Rules of Procedure and Evidence (R PE)

As stated earlier, Article 51(3) includes an exception to the general rule under Article 51(2) making it possible for judges to adopt rules provisionally, to deal with an urgent situation not catered for by the rules. It states:

After the adoption of the Rules of Procedure and Evidence, in urgent cases where the Rules do not provide for a specific situation before the Court, the judges may, by a two-thirds majority, draw up provisional Rules to be applied until adopted, amended or rejected at the next ordinary or special session of the Assembly of States Parties. ${ }^{47}$

These rules that are provisionally adopted by the judges must therefore be adopted by the ASP. ${ }^{48}$ In a way Article 51(3) appears to serve as a compromise between the advocates of stringent observance of the principle of legality

\footnotetext{
46 Ambach, supra note 22, at 864.

47 Rome Statute, Article 51(3).

48 Broomhall, supra note 7 , at 689.
} 
and those who emphasized on flexibility and the Court's ability to function efficaciously. ${ }^{49}$

However, speculation on legislative intent aside, the purpose of the aforesaid provision appears clear. This is to allow judges, under the circumstances to deal with situations that are not catered for under the existing RPE. ${ }^{50}$ It therefore accommodates the notion of institutional adaptability. ${ }^{51}$ Historically judges have not availed themselves of this provision prior to the adoption of Provisional Rule 165, and have instead chosen repeatedly, to propose legislation through the mechanism under Article 51(2) in view of enhanced transparency and dialogue. ${ }^{52}$

\subsection{Legal Framework for Adopting, Amending or Rejecting Provisional Amendments}

This sub-section discusses the powers of the ASP in relation to a provisional rule adopted by the Court under Article 51(3). After discussing the nature of the decision under Article 51(3), it analyses the actions the ASP is authorized to take under the provisions of the Rome Statute. It then assesses the response of the ASP to the adoption of the provisional Rule 165, and the implications thereof.

\section{2 .1}

Nature of Decision to Adopt Provisional Amendments under Article 51(3)

The proposal for such 'provisional amendments' to the Rules, or 'provisional rules' can be submitted by the Presidency, the Prosecutor or a judge, to the plenary. ${ }^{53}$ The term 'Plenary Session' 54 refers to both regular plenary sessions of the judges that are to be held at least once a year to exercise their functions under the Statute and the Rules and Regulations, as well as special plenary sessions, called by the President. The Quorum for the Plenary is two-thirds of the judges. ${ }^{55}$ It is relevant to keep in view the nature of decisions that that the Court takes during plenary sessions in order to properly examine the nature of such a decision under Article 51(3). These include the adoption of the Regulations of

49 See G. Boas, 'Comparing the ICTY and the ICC: Some Procedure and Substantive Issues', 47(3) (2000) Netherlands International Law Review 267-292, at 271.

$5^{\circ} \quad$ Rome Statute, Article 51(3).

$5^{1} \quad$ Broomhall, supra note 7 , at 1035.

52 ASP, Report of the Working Group on Amendments (2012), ICC-ASP/11/36 at 2. The judges have also not resorted to this provision during the two years since the adoption the Provisional Rule 165 .

53 Regulations of the Court, ICC, Regulation 51(2).

54 Ibid., Regulation 2.

55 Rules of Procedure and Evidence, ICC, Rule 4. 
the Court, electing the Presidency, the Registrar, as well as Deputy Registrar ${ }^{56}$ and the removal from office, of a judge, ${ }^{57}$ the Registrar or Deputy Registrar. ${ }^{58}$

While judges are authorized to adopt such provisional amendments to the $\mathrm{RPE}$, these are transitional in nature and are to be adopted, amended or rejected by the ASP. Further, the status of the provisional amendments in a situation where the ASP does not decide whether or not to adopt such amendment was discussed within the WGA, including in its sixth meeting in relation to provisional Rule $165 \cdot{ }^{59}$ It was observed that the issue be left for the Court to adjudicate on. ${ }^{60}$ Not all States Parties expressed agreement with this view.

It was the view of the Kenyan Government that the conditions for the exercise of the power under Article 51(3) were not fulfilled in the present case. ${ }^{61}$ In the letter addressed to the President of the Bureau, the Attorney General of the Government of Kenya went as far as stating that exercise of power under Article $51(3)$ by the judges must be 'properly scrutinized' ${ }^{62}$

Article 51(3) specifies the circumstances under which the judges acting in plenary can adopt provisional amendments to the RPE. If these are to be considered pre-conditions for the exercise of power under Article 51(3), the subsequent question that arises is whether the ASP has the power to examine whether or not these 'pre-conditions' have been met. According to Professor Broomhall, it is for the judges themselves to 'initially' determine whether or not the conditions required for them to be able to exercise this power under Article 51(3), have been met. ${ }^{63}$ Once again while assigning primary authority to the judges themselves to decide whether such exigent circumstances exist, this theory does not preclude that the decision is non-reviewable. On a perusal of the relevant provisions of the Rome Statute, the constituent instrument of

$56 \quad$ Ibid., Rule 12.

57 This is in consonance with the practice of other International Courts and Tribunals whereby judges can only be removed 'by the Court itself'; see R Mackenzie and P. Sands, 'International Courts and Tribunals and the Independence of the International Judge', 44(1) Harvard International Law Journal (2003) 271-285, at 279.

$5^{8}$ Rules of Procedure and Evidence, ICc, Rule 29.

59 ASP, Report of the Working Group on Amendments (2016), ICC-ASP/15/24, at 6 (Mr. H. Abtahi the first Principle Legal Advisor to the Presidency, invited by the Chairperson of the WGA, to the sixth meeting of the Working Group); see also ASP, Report of the Bureau on the Study Group on Governance (2016), ICC-ASP/15/24.

6o Ibid., at Add. 1.

61 Letter from the Attorney General of Kenya to the President of the Assembly, dated 17 March 2016, at 12.

$62 \quad$ Ibid., at 13 .

63 Broomhall, supra note 7 , at 1043 . 
the ASP, as a treaty organ ${ }^{64}$ it does not prima facie appear to have been granted powers of review. Neither does the Statute address the implications of a provisionally adopted rule being subsequently rejected by the AsP. This would in all probability, raise questions in relation to the legitimacy of the rule applied to the case under consideration. There does not appear to be an appropriate means of addressing this question. Therefore, a decision on the matter by either the Court or the ASP could raise issues of interference with each other's mandate.

The status of orders issued under such a provisional rule, in a situation where the ASP has subsequently rejected the provisional rule has been speculated, although the situation has not arisen yet. ${ }^{65}$ It has been suggested however that the issue would be dealt with through adjudication by the judges.

\section{2 .2}

Extent of Powers of the ASP in Relation to a Provisionally Adopted Amendment to Rules of Procedure and Evidence (RPE)

The Rome Statute stipulates that such a provisional rule must be transmitted to the President of the Bureau of the ASP, and consequently to the States Parties. It also specifies that the provisional rule in question is to apply until it is subsequently adopted, amended or rejected by the next session of the ASP, and the fact that there must be efforts to reach a consensus on the matter, if possible. ${ }^{66}$

As far as the internal mechanisms and processes are concerned, these ought to be observed through the manner in which the AsP dealt with the adoption of provisional Rule $165,{ }^{67}$ which as stated earlier is the first recourse to the provision under Article $51(3)^{68}$ taken by the Court.

64 See Niels Blokker, 'The Governance of International Courts and Tribunals, Organizing and Guaranteeing Independence and Accountability', in Andreas Follesdal and Geir Ulfstein (eds.), The Judicialization of International Law, a Mixed Blessing? (Oxford University Press, Oxford, 2018), p.29.

65 Boas, supra note 49 at $272-273$. While the 2018 Report of the Working Group on Amendments refers to the application of this rule, this reference appears to be misplaced and inaccurate.

66 Rome Statute, Article 112(7).

67 For a detailed description of the newly adopted provisional rule and comparison with the original rule, see Report on the Adoption by the Judges of Provisional Amendments to Rule 165, supra note 1, at 3-4.

68 ASP, Report of the Study Group on Governance Cluster I in relation to the provisional amendments to Rule 165 of the Rules of Procedure and Evidence, (2016) ICC-ASP/15/7, at 2. 
The President of the Court in her letter dated 29 February 2016, to the President of the $\mathrm{ASP}^{69}$ informed the latter of the adoption of provisional Rule 165 on 10 February 2016, by the judges acting unanimously in plenary and transmitted along with the letter, a Report ${ }^{70}$ on the provisional rule. Subsequent to this, the Bureau of the ASP decided that the matter should be transmitted to, and discussed within, the Study Group on Governance (Cluster I) (SGG), in The Hague, following which, it should be dealt with by the WGA, based in New York. ${ }^{71}$ The Bureau was of the view that this provided the States an adequate platform to examine the issue in order to address it at the fifteenth session of the ASP. ${ }^{72}$ The SGG dealt with the matter through three sessions of informal consultations but could not reach a consensus, although a majority of the States appeared to be in favour of the provisional rule. The SGG then proceeded to transmit the amendment as it were to the WGA without a concrete recommendation but enclosing the views expressed within the SGG and the responses that they received via the Court. ${ }^{73}$

The WGA began deliberating the matter on 28 September 2016, and in its Report prior to the fifteenth session of the ASP, expressed its inability to take a final decision and decided to continue deliberations at the fifteenth session of the ASP. ${ }^{74}$ The same Report also refers to the fact that some delegations expressed concern in relation to whether the criteria under Article 51(3) had been met. While acknowledging that the majority were of the opinion that this was indeed the case, and referring to the fact that the provisional rule had been adopted unanimously by the judges, the Report also documents the suggestion that the Court should endeavour to submit proposals directly to the ASP instead of direct recourse to the provision under Article $51(3) .{ }^{75}$ France and Germany, on the other hand jointly submitted a 'non paper' on the issue, proposing certain amendments to the provisional rule, and while doing so, took note of the apprehensions expressed by certain delegations in relation to the 'two criteria in article $51(3) \cdot{ }^{76}$

\footnotetext{
$69 \quad$ Ibid., Annex I, at 6.

$70 \quad$ Ibid., Annex II, at 7-11.

71 ICC-ASP, Bureau of the Assembly of States Parties, Agenda and Decisions, First Meeting, New York, 1 April 2016, at 2.

$72 \quad$ Ibid.

73 ASP, Report of the Study Group on Governance Cluster I in relation to the provisional amendments to rule 165 of the Rules of Procedure and Evidence, (2016) ICC-ASP /15/7, at 5 .

74 ASP, Report of the Working Group on Amendments, (2016) ICC-ASP/15/24, at 7.

75 Ibid.

$76 \quad$ Ibid., at 7 .
} 
The Report mentions the letter by the Attorney General of the Government of Kenya to the President of the Bureau of the ASP which postulates the need to scrutinize the decision of the judges to take recourse to the provision under Article 51(3). This raises the question of whether the powers of the ASP under the Rome Statute as well as the RPE themselves, to adopt, reject, or amend the provisional rule as adopted by the judges, extend to what can only be described as essentially a review of the decision of the judges under Article 51(3).

Interpretation based on the ordinary meaning of the words of the provision would imply that such action by the ASP cannot be taken, except in the form of reasons underlining the decision to either adopt, amend or reject the amendment. Arguably, if the ASP is of the view that no 'urgency' or situation demanding the application of the amended rule exists, it has the authority to reject the provisional amendment to the rule as envisaged under Article 51(3). However, whether the ASP has other powers in relation to treating the provisional amendment as ultra vires and consequentially suspending its application, appears doubtful on a perusal of the text of the relevant provisions.

At the fifteenth session of the ASP, the States within the forum of the WGA continued to debate and discuss the issue of provisional Rule 165, and accordingly adopted two addendums to its Report dated 8 November 2016. It is of vital importance to note that Addendum I to this report under 37 bis acknowledges the opinion of certain delegations that the provisional rule as it is should not be applied by the Court prior to a decision taken by the ASP. At the same time under 37 ter, the WGA notes that other delegations expressed their views in favour of the application of the provisional rule until the ASP is in a position to take a decision on the provisional amendment. This is followed by an observation by some States that 'it was not for the Assembly to pronounce itself on this issue as it was for the Court to adjudicate the matter.'77 This is particularly interesting as this follows a deliberation over whether the provisional rule, prior to being adopted, rejected or amended, should in fact be applied by the Judges. While, the non-application of such provisional rule would seemingly appear to defeat the raison d'être of Article 51(3), this statement appears to be an acknowledgement of the existence of limitations on the power accorded to the ASP through Article 51(3). Additionally, however, the fact that these issues were being considered within this forum put the WGA at the risk of overstepping the ASP's mandate into the arena of the Court.

The question that subsequently arises is, whether discussing the application of the provisional rule in the first place as well as contemplating the 
possibility of suspending the application thereof, is in itself a deviation from the contours of the powers allotted to the ASP under Article 51(3). If the answer to this is in the affirmative, is the adoption of the addendum, which concludes that this falls under the mandate of the Court, sufficient to tend to this abrogation? Since the role of the WGA is to provide the ASP with recommendations on the issue of the provisional amendment, the observation as assiduously documented, could prove to assuage the ASP from taking a decision on the application of the provisional rule until a final decision as to the adoption, amendment or rejection of the amendment. Nevertheless, it must be highlighted that the Statement of Kenya as annexed to the official records of the fifteenth session of the ASP, requests that the Court abstain from applying the provisional rule. While this is a part of the official record, a plain reading of the text within the framework of the overall mechanism and functioning of both the Court and the ASP, would imply that this is in the form of a request to the Court, and a vehicle of registering the apprehensions of the State concerned, thereby not effectively orchestrating the adjudication of this matter by the Court.

Ultimately, based on the powers assigned to the ASP under Article 51(3) read with Article 112, the ASP is competent to accept the provisional amendment if it is in agreement with the Court on the need to adopt it. Alternatively, it can also amend or reject the amendment in its entirety. This however appears to represent the entirety of the ASP's powers on this issue. This would thus preclude any potential analysis of whether the substantive conditions under Article 51(3) have been met, or a suspension of the provisional rule pending a decision. The ASP however did not take a decision at its next session. Neither has it made such a decision in the following two meetings of the ASP.

The absence of a decision in this respect raises several issues. There has been reference to a possibility of an 'automatic rejection' of the provisional rule. However, this concept raises the question of whether Article 51(3) could similarly be interpreted to imply an automatic acceptance. The premise of the latter is particularly problematic, since the provision clearly requires affirmative action on the part of the ASP, underscoring the provisional nature of the rule.

Unlike in the case of the Regulations of the Court, the Statute does not stipulate a situation where the States are required to merely raise objections within a given time period. It could similarly be argued that the provisional amendment to the rule 'lapses' at the next session of the Assembly of States Parties. This however is again problematic since this strays from the ordinary meaning of the text under Article 51(3). Moreover, the question of Rule 165 has appeared intermittently on the agenda of the WGA in the two years since its adoption by the Court. 
Therefore, the notion of either an automatic rejection or automatic acceptance appears to deviate from an interpretation of Article 51(3) based on the ordinary meaning of the words. ${ }^{78}$ The provision requires affirmative action on the part of the ASP and unambiguously states three ways in which the ASP can respond to such provisional adoption of an amendment to the RPE by the judges. Suspension is clearly not provided for under this provision. Therefore, the decision of the ASP not to decide this in its fifteenth session, which was 'the next session' within the purview of Article 51(3), amounts to an exercise of its authority or abdication thereof in a manner which is not catered for under the Rome Statute.

\subsubsection{Criticism of a de-facto Review of the Decision under Article 51(3)}

The issue of whether the criterion under Article 51(3) had been met was actually discussed, within the framework of the SGG as well as in the WGA, along with the issue of the provisional application of the provisional rule. ${ }^{79}$ Determining whether there was 'urgency' and whether the rules did not in fact 'provide for a specific situation,' effectively amounts to a review of the decision of the Court.

The Rome Statute while determining the scope of the ASP as the Judicial Governance institution of the Court, does not attribute to it powers of review. The ASP has discretion to carry out 'functions that are consistent with the Statute or the Rules of Procedure and Evidence' 80 , however the ASP cannot, as a treaty based ${ }^{81}$ governance institution, assume power not expressly provided. ${ }^{82}$ To conclude that the ASP does in fact have the power to review such a decision could raise uncertainties, by lifting the barriers between the mandate of the AsP and the Court.

78 See for e.g., Constitution of the Maritime Safety Committee of the Inter-Governmental Maritime Consultative Organization, Advisory Opinion, 8 June 196o, [1960] ICJ Rep. 159-160, citing the Court's opinion in Competence of the General Assembly for the Admission of a State to the United Nations, Advisory Opinion, 3 March 1950, [1950] ICJ Rep., at 8.

79 ASP, Report of the Study Group on Governance Cluster I in relation to the provisional amendments to Rule 165 of the Rules of Procedure and Evidence, (2016) ICC-ASP/15/7, at 2.

$80 \quad$ Rome Statute, Article $112(2)(\mathrm{g})$.

81 This can also be seen as being in consonance with the fact that the ICC is not a supranational institution in terms of all of its functions and is based on a Treaty between States; see M.C. Bassiouni, 'The ICC - Quo Vadis?', 4 Journal of International Criminal Justice (2006) 421-427, at 422; cf. A. Bos, 'Assembly of States Parties', in Cassese et al. (eds.), supra note 11 at 103 .

82 H.G. Schermers and N.M. Blokker, International Institutional Law (Brill Nijhoff, Leiden, 2011) at 503 . 
This would also set forth a potentially dangerous precedent forming the basis for standard practice and could hypothetically be used by the States Parties as a vehicle to review decisions that they do not agree with. More importantly this implies a situation wherein the ASP assumes a role that it was not allotted under its constitutional instrument. The Rome Statute does not articulate a hierarchy between the ASP and the Court. ${ }^{83}$ Therefore it would seem inappropriate for the ASP to assume the position of an appellate board, effectively reviewing decisions of the Court.

\section{3}

\section{Independence vs. Accountability}

This section highlights the need to balance accountability of the ICC, with judicial independence. It considers the scope for the AsP to operate beyond its mandate, as illustrated under section 1. In light of the legal separation of powers between the ASP and the ICC this section analyses whether in practice, there is an overlap of mandate between the Court and its international judicial governance institution (injugovin). ${ }^{84}$ This is with an objective to evaluate whether the overreach identified in section 1 can be attributed to individual transgression or lacunae in the law.

\subsection{Overlap of Mandate between the AsP and Icc}

The Rome Statute prescribes the ASP a specific role, separate from that of the Court itself. A review of practice in this regard depicts a tendency for a slight overlap in competencies. This is enhanced by the need for the Court to make certain choices in light of its wide-reaching jurisdiction and permanent nature.

However, there are examples demonstrating the possibility of the ASP to deliberate issues that appear to fall under the domain of the Court. The 'Principals of the Court' in a joint letter addressed to the President of the ASP, referred to a note verbale addressed to the Assembly, which in their opinion transgressed into the domain of the Court. The letter indicated that the note verbale in question prima facie raised issues that ordinarily fall within the purview of judicial matters. These include matters that have already been adjudicated, those sub judice, as well those matters that should ordinarily be adjudicated on, in due course in consonance with the relevant procedure and legal framework. ${ }^{85}$ The

\footnotetext{
83 Blokker, supra note 64 .

84 Ibid.

85 ICC, Letter to the President, Assembly of States Parties to the Rome Statute, 7 November 2014, at 1; for an analysis of this see Blokker, supra note 64.
} 
letter further stated that the Court appreciated the duty of the Assembly to provide management oversight to the Presidency, the Prosecutor and the Registrar regarding the administration of the Court ${ }^{86}$ reiterating that such oversight must not compromise the independence of the Court. ${ }^{87}$ The letter urges the Bureau to ensure that items on the agenda of the ASP remain confined to matters within its competence. ${ }^{88}$ Further the tendency or the mere possibility for transgression is reflected through the manner in which the Asp dealt with the adoption of provisional Rule 165 . There are also frequent deliberations that relate to the interpretation of certain decisions of the Court.

This demonstrates the possibility for the ASP to transgress, even if slightly, to what would appear to be the domain of the Court. It is important therefore, to scrutinize whether this is in fact the result of individual transgression on behalf of certain States, or whether it can be attributed to an absence of adequate safeguards within the legal framework of the Court.

\subsection{Individual Transgression or Lacuna in Law}

In the two instances cited above, that is, the one referred to in the Letter of the Court to the ASP and the instance concerning Article 51(3), the consideration of issues seemingly beyond the mandate of the ASP, could be attributed to the State proposing such supplementary agenda items, or delivering such statement respectively. However, it is necessary to acknowledge that the ability of a State to transgress reflects the incapacity of the prevailing legal structure to prevent such transgression. This therefore demonstrates a significant oversight in the legal framework, which could plausibly be attributed to textual ambiguity and deficiency in formal delineation of mandate and procedural detail. Changes to the institutional structure have been proposed under section 3 .

Similarly, it is important to acknowledge that a review of final decisions of the ICC, is not expressly listed as being within the competency of the ASP. However, there is visibly an absence of clear delimitation and a latent overlap of competency between the Court and its injugovin in relation to certain procedural and policy related matters. The ambiguity in delineating the functions and authority of the ASP with precision creates the risk of misinterpreting such provisions to include powers not expressly conferred to the ICC's injugovin. The lack of certainty in relation to what the ASP can and cannot do, as an injugovin to the ICC, makes it possible for the ASP to essentially review such decisions of the Court. As discussed in section 1 this was demonstrated by the

\begin{tabular}{ll}
\hline 86 & Ibid. \\
87 & Ibid. \\
88 & Ibid., at 2.
\end{tabular}


ASP's willingness to discuss and place on record, an analysis of the reasoning and basis underlining the judges' decision to provisionally amend Rule 165 .

Therefore, the ability of the ASP to carry out a review of the decisions of the Court, even superficially, can be attributed to an unclear division of power and function and subsequent interpretation thereof. While there might not be any guarantee against such individual transgression, this needs to be addressed through institutional mechanisms and safeguards within the ASP as well as its subsidiary organs. This is indispensable to ensure a favourable balance between the accountability of the Court to its injugovin and its own independence.

\section{Ensuring Independent Judicial Function: Limits on the Powers of} the ASP

As discussed in section 1, the manner in which the AsP dealt with the adoption of provisional Rule 165 was not provided for in the Rome Statute. This action has a twofold effect on the judicial function of the Court. The first, in the form of a de facto review of the Court's decision under Article 51(3), the second, it appears to have left the state of law in a flux, directly affecting judicial function. As identified in section 2, overreach by the ASP can be attributed to the possibility of individual transgression, which is possible through ambiguity in the legal framework and delineation of competencies between the ICC and ASP.

This section therefore considers the plausibility of the ASP actually reviewing such decisions of the Court. After discussing the legal implications of this, this section analyses certain safeguards to prevent any transgression. These include those within the prevalent legal regime, and in addition thereto. It considers using the concept of decision-making by consensus as a check on such transgression. This section then advances a proposal to amend the powers of the Chairperson of the WGA, to address the lacuna created by the existent provision under Article 51(3). Finally, it concludes with a holistic analysis of the curious case of Article 51(3), and how the present proposal can be applied to address the resultant lacunae in the law.

\subsection{Plausibility of a Review of Plenary Decisions}

While dealing with the issue of a de facto review of the Court's decision under Article 51(3) as an overreach by the ASP, it is important to actually consider the actual plausibility of such a review. While this is not provided for under the Rome Statute, this section considers the feasibility of such a review and 
whether it would be favourable in light of its practical and legal implications. This evaluation is in light of the merits, demerits, and availability of forum for such a review.

\subsubsection{Merits of such a Review}

A review of decisions of the Court under Article 51(3) warrants favour for the same reasons that underlined the decision to allot legislative prerogative to the ASP in the first place. This is to ensure the separation of judicial and legislative powers. While the Court may adopt provisional rules under expedient circumstances, the ASP would be able to review what is essentially delegated legislative competence.

Since the decision of the Court in these circumstances is in exercise of an exception to the legislative exclusivity of the ASP, a certain degree of review or appraisal appears logical. This would additionally be in consonance with the concept of 'institutional balance'. ${ }^{89}$

The greatest factor in support of such review is the need to discuss the substantive issues underlying the provisional amendment. Most deliberations within the forum of the ASP, especially in relation to the provisional amendment appear to lack thorough deliberation of the legal issues incumbent in the provisionally adopted rule. Possible review might steer the attention of States to the substantial aspects of the provisional rule. This would be in conformity with the intention of the States to ensure that the ASP retains legislative power. Further, such a review could form the basis of the decision of the AsP to adopt, amend, or reject the provisional rule.

Moreover, in view of the intention of the States to enable the ASP to deliberate over legislative matters, in a manner relatively akin to national criminal jurisdictions, there is merit in the ability of the ASP to review whether or not there was in fact 'urgency' which necessitated the extraordinary legislative action by the Court. This is important to ensure that this procedure is not misused, in a manner to 'assume legislative power indefinitely'.

\subsubsection{Relevant Forum for Such Review}

A major concern in relation to a potential review of such decisions of the Court, is the want for an appropriate forum for such review. One could argue in favour of the ASP Bureau as such a forum. However, this might not be welcomed by all States Parties. This is because first, the Bureau is representative in

89 See in relation to the concept of 'institutional balance', Schermers and Blokker, supra note 82 , at 170 . 
nature. ${ }^{90}$ While this has its advantages in the form of the logistical feasibility of substantive discussions, carrying out a function as important as the review of the decisions of the Court, without the involvement of all the members of the ASP might raise concerns.

Second, the ability of the Bureau to review such decisions might essentially affect the manner in which its members are elected. This is especially, in light of the technical legal nature of matters that might fall under such review. Therefore, the composition of this body is crucial and may need to be altered to facilitate the successful review of such decisions and meaningful deliberations.

Third, the prospect of the Bureau as a forum of review might face opposition, keeping in view that during the negotiations for the establishment of the ASP, the term 'Council' was rejected. This was based on the implications of the use of such term and the fact that the States did not wish for the Bureau to exercise such powers as a corollary thereto. ${ }^{91}$

It is important to note in this regard, that even if the Bureau was designated as the appropriate forum for such a review, the final decision on this would have to be taken by the ASP as a whole. In practice this would imply, a decision taken by the ASP Bureau in the form of a draft resolution, followed by a plenary session of the ASP, where the draft resolution would be introduced. Subsequently, the President would ask the Assembly if he or she 'can take it that the Assembly wishes to adopt the resolution or report of the Bureau', and then in quick succession, unless there are any objections raised immediately, state that 'it is so adopted. ${ }^{92}$

However, it appears unlikely that such a path for reviewing decisions of the Court would in fact be chosen. The manner in which the ASP functions, or the institutional structure adopted by the States Parties in this regard, appears unequipped to deal with the review of decisions by the Court. This is not surprising, since the ASP was not established as an appellate or even a judicial or quasi-judicial body. It is the governance body to the ICC, tasked with important legislative and governance functions. This is apparent through the manner in which it is structured. This includes the expressly conferred power of

9o Rome Statute, Article 112(3), Bureau shall be representative in character, cognizant of geographic distribution and adequately represent the principle legal systems of the world; S. Rama Rao, 'Article 112 Assembly of States Parties', in Triffterer and Ambos (eds.), supra note 7 , at $2231-32$.

91 S. Rama Rao, 'Financing of the Court, Assembly of States Parties and the Preparatory Commission', in Roy S.K. Lee (ed.), The International Criminal Court. The Making of the Rome Statute: Issues, Negotiations and Results (Kluwer Law International, The Hague, 1999), at 412, at 410. 
the ASP to establish subsidiary bodies, and the subsequent establishment of the WGA, and other working groups that deal with substantive deliberations. Such a format comprising working groups, or even 'facilitation', would be an unfit mechanism to deal with a matter as technical such as the review of the decisions of the ICC.

Further still, the ASP is empowered to establish subsidiary bodies specifically for the purpose of exercising its functions. ${ }^{93}$ This would therefore rule out the possibility of establishing an additional body to exercise such powers of review, in view of this being beyond the scope of the AsP's functions.

States could use plenary sessions to initiate the process of consultations, in relation to matters including the issue of Article 51(3). An example of this is the statement by Argentina concerning the desirability to adopt the amendment to the RPE as provisionally adopted by the judges. ${ }^{94}$

However, while plenary sessions are the ideal place to bring certain issues to the attention of the States so that they can be used as building blocks for the negotiating process, these sessions are not equipped to deal with matters such as the review of decisions of the Court. A review of this nature essentially amounts to a quasi-judicial, if not judicial function, and therefore requires all the pre-requisites that underline judicial function especially in relation to the composition of such members who would be qualified to make such a deliberation. There is a visible lack of an appropriate forum for the performance of such a review. This absence of forum is grounded in the institutional structure adopted by the States Parties, which was not aimed at establishing an appellate body.

\subsubsection{Demerits and Lack of Legal Basis for such Review}

It is important to acknowledge the context in which the Court adopts a provisional amendment to the RPE under Article 51(3), which is the main focus of this study. Such provisional rules are adopted in urgent cases that necessitate expedient action to enable the Court to deal with situations not catered for through the existing Rules. Review subsequent to such adoption, would give parties involved in such cases, fuel to challenge the decision of the Court. This would ultimately undermine both the decision, and authority, of the Court.

To a certain extent, an appraisal of the Court's decision under Article 51(3) by the ASP has been catered for vis-à-vis its ability to adopt, amend or reject such provisional rules. Choosing not to exercise any of the three actions provided

93 Rao, Article 112, supra note 9o, at 1694.

94 República Argentina, Statement of the Argentine Delegation, General Debate, 15th Session of the Assembly of States Parties, The Hague, 16 November 2016, at 3. 
for in the Statute, and instead reviewing whether or not the judges correctly interpreted the need to exercise such powers, falls outside the strict contours of the provision. There are certain disadvantages that would accrue through such an assumption of the 'power to review' by the ASP.

Apart from the lack of a forum for such review as discussed earlier, there does not appear to be sufficient legal basis for such review of decisions by the ASP. In response to the argument of this being within the implicit powers of the ASP, such implicit powers must be in furtherance of the objectives of the organization in question, which does not appear to be the case here. ${ }^{95}$ While the Rome Statute does not explicitly lay down objectives of the ASP, it does however, specify functions that the ASP is to perform. Article 112(2) lists seven functions and includes a residuary provision catering for the ASP to 'perform any other function consistent with this Statute or the Rules of Procedure of Evidence'. The other six functions preclude any reference to any such review.

Potentially, a review of the decisions of the Court, would have to fall under the management oversight function of the ASP, or under the residuary functions of the ASP. Both, these premises are riddled with complex difficulties that make them unsuitable for the provision of such legal basis. In relation to the former, it is important to note that while the earlier use of the term 'non-judicial administration' as discussed was discontinued, the function of 'management oversight' per se cannot be said to include the review of decisions. Neither can the latter or 'residuary functions' of the ASP be presumed to confer the power to review decisions. According to this provision, the ASP can perform functions other than those specifically detailed under the Statute however these must be compatible with the provisions of both the Rome Statute itself, as well as the RPE. ${ }^{96}$ In view of the consequential impact of such a review on judicial functions of the Court, exercising such a power to review decision would ordinarily lie beyond this ambit. ${ }^{97}$

In relation to the decision of the Court to adopt a provisional rule under Article 51(3), the Statute provides three clearly defined approaches for the ASP to decide between. These are, to adopt, amend or reject the rule and nothing

95 See Legality of the Use by a State of Nuclear Weapons in Armed Conflict, Advisory Opinion, [1996] ICJ Rep., 66 at 79; the Court cited its opinion in the Reparations Case, where it referred to the Advisory Opinion of the Permanent Court of International Justice, see, Competence of the International Labour Organization to Regulate, Incidentally, the Personal Work of the Employer, Advisory Opinion No. 13, 18.

96 Rao, Article 112, supra note 9o, at 1692-1693.

97 See for a discussion on the ambit of 'any other function', ibid., at 1692. 
more. This rules out prima facie, any additional action by way of a review of the decision of the Court.

Arguably, if such a power to review the decisions of the Court were to be assumed by the ASP, it would be without sufficient legal basis. Such assumption could lead to possibility for the ASP to intervene in the judicial process or assume powers attributable to a court of appeals. In addition, as this power is not expressly granted to the ASP there are no parameters to regulate its exercise of such power. Therefore, for want of legal basis and the implications that follow, such review ought not to be permitted.

Thus, a review would give rise to uncertainty in terms of procedure and associated safeguards or lack thereof. This would effectuate procedural unambiguity, and subordination of the Court's authority in terms of powers expressly granted to it under its Constituent instrument.

\subsection{Mechanisms for Preventing Transgression including the Essential Review of Decisions}

On one hand inherent legal safeguards such as the guarantee of judicial independence could itself limit the powers of the ASP ${ }^{98}$. However, on the other hand, as highlighted by the manner in which the ASP dealt with the provisional amendment of Rule 165 by the Court, there is scope for the ASP to overreach. It is important therefore to discuss safeguards and mechanisms present both within and outside the present legal regime of the Rome Statute. Within the existing provisions of the Statute, this sub-section analyses whether decision making through consensus can be utilized as a tool to ensure compliance of States with the Rome Statute. It then proposes, the amendment of the role of the Chairperson of the WGA, to effectively combat the issue of individual transgression.

4.2 .1

Safeguards within the Decision-Making Process of the ASP:

Decision Making by Consensus as a Check on the Powers of the AsP

There was agreement amongst States to the Rome Statute, to encourage decision-making by consensus. ${ }^{99} \mathrm{In}$ cases where such consensus is not possible the

98 This is further reinforced by the objective of the ASP to provide a forum for accountability of the ICc. For e.g., see in relation to the reference to the need for 'demanding institutional accountability', the Statement by Ambassador Rose Makena Muchiri, Republic of Kenya, during the Assembly of States Parties, The Hague, 17 November, 2016, at 6.

99 Rao, Financing of the Court, supra note 91, at 410. 
Statute provides for a vote. ${ }^{100}$ This also applies to the subsidiary bodies established by the ASP. ${ }^{101}$ This therefore includes the WGA.

While the Rules of Procedure of the ASP do not define the term consensus itself, Rule 61 states clearly, that 'Every effort shall be made to reach decisions in the Assembly and in the Bureau by consensus. If consensus cannot be reached, decisions shall be taken by vote. '102 The use of both 'every' and 'shall' are significant here, albeit for different reasons. Specifying that every effort must be undertaken to try and reach decisions by consensus, indicates the threshold for assessing such efforts. On the other hand, the fact that the rule then provides that in the absence of consensus, the decision shall be made through a vote, ensures that the lack of a consensus does not bring the decision-making process to a standstill. ${ }^{103}$ Nonetheless consensus-based decision making is encased with the 'shadow of a vote.'104

To appreciate decision-making by consensus as a possible mechanism to prevent transgression it is important to realize what this process implies. Consensus as a form of decision-making is often defined as decisions made in the absence of formal objections. More generally, it is defined as a 'general agreement' or 'collective opinion'. ${ }^{105}$ Ordinarily, this entails the President asking if he or she should 'take it that the assembly wishes to adopt the resolution'. Swiftly then, in the absence of such objections, he or she then announces that 'it is so adopted.'.106

\footnotetext{
100 Rome Statute, Article 112(7).

101 Rules of Procedure of the AsP, Rule 61, Rule 84.

102 Ibid., Rule 61; see The Agreement Establishing the World Trade Organization, Article IX(1).

103 This additionally reinforces that the requirement for efforts towards decision-making through consensus, should not be misunderstood to imply 'unanimity'. Decisions taken through 'unanimity' usually imply decisions by voting, see in relation to this, Schermers and Blokker, supra note 82 , at $547-549$; where such unanimity is intended, it is ordinarily specified in the instrument governing such decision-making; see for e.g., The North Atlantic Treaty (1949), Article 10.

104 Consensus based decision making is said to be encased with the 'shadow of a vote', in relation to this, see Claus-Dieter Ehlermann and Lothar Ehring, 'Decision Making in the World Trade Organization', 8(1) Journal of International Economic Law (2005) 51-75, at 52; this has also been mentioned in relation to what is described as 'the delicate paradox that it should, and should not be, taboo to vote', Schermers and Blokker, supra note 82, at 535 .

105 See for e.g., Bryan A. Garner, Black's Law Dictionary, Ninth Edition (West Group, St. Pauls, MI, 1999), at 345 .

106 See UNJY, 2003, at 533; also discussed in, Schermers and Blokker, supra note 82, at 533-534.
} 
This method of decision-making is therefore, characterized as being inclusive, participatory, and 'solution oriented'.107 This is largely based on the reluctance of States to resort to a vote. The need to resort to a vote is often seen as a failure in this respect. ${ }^{108}$ So far the ASP has favoured consensus-based decisions even where the Rome Statute envisioned a vote, such as in the case of the procedure adopted for the election of the Prosecutor. ${ }^{109}$

The overwhelming inclination of States Parties towards decisions by consensus has also been identified as one of the factors that facilitated a decision on the extremely delicate issue of the Crime of Aggression. ${ }^{110}$ The Kampala Amendments have been referred to by those involved as reflective of the spirit of compromise and flexibility, inherent in the processes of decision making by consensus. ${ }^{111}$ Therefore the visible willingness of States Parties as depicted in the past, to address the concerns of other States, is what acts as a check against any transgression on the part of the ASP itself. ${ }^{112}$

Thus, the increased level of flexibility and willingness to negotiate creates a common platform for all States to voice their concerns and views. This effectively acts as a check on any potential transgression of mandate. This is because the ASP would dissuade the States that might inadvertently delve into deliberations beyond the competency of the ASP, from doing so. This can be attributed to the view that the ASP is less likely to collectively violate the Rome Statute or interfere with the operation of the Court. Therefore, the process that leads to consensus-based decision-making or generally the features

107 See East African Court of Justice, Council of Ministers of the East African Community, Application No. 1 of 2008, Decided on January 1, 2009, Advisory Opinion, at 4, referring to 'H. G Schermers and N.M. Blokker'.

108 This has also been referred to by Ambassador Wenaweser, former President to the ASP. He stated in relation to the Review Conference at Kampala, and the process leading to it, that 'for many, a vote was per se- irrespective of its outcome and of the substance of a proposal on the table- anathema', see Christian Wenaweser, 'Reaching the Kampala Compromise on Aggression: The Chair's Perspective', 23 Leiden Journal of International Law (2010) $883-887$, at 884 .

109 Rome Statute, Article 42(4), read with, 'Procedure Adopted for the Nomination and Election of Judges, the Prosecutor, and the Deputy Prosecutors of the International Criminal Court, ICC-ASP/3/Res.6, (consolidated version), at 5 .

110 Schermers and Blokker, supra note 82, at 543.

111 See for e.g., Stefan Barriga, 'Negotiating the Amendments on the Crime of Aggression', in Stefan Barriga and Claus Kreß (eds.), The Travaux Préparatoires on the Crime of Aggression (Cambridge University Press, Cambridge, 2011) at 3; see also Wenaweser, supra note 108 , at 887 .

112 See for e.g., Wenaweser, ibid., at $883-884$. 
thereunder, effectively help address issues that could potentially lead to the individual transgression discussed in section 1.

Another mechanism used to gain such consensus is the example of the 'agreed text of understandings' as in the case of defining the Crime of Aggression. ${ }^{113}$ This could further work towards preventing misinterpretations of the Statute or of the mandate of the ASP.

While the ASP is less likely to act in violation of the Statute collectively, this does not completely rule out the possibility however slight, of the ASP choosing to act against the Rome Statute through consensus. This is relevant in particular in light of the inaction of the ASP in relation to the provisional rule adopted by the Court as discussed in section 1 .

4.2.2 Proposal for Strengthening the Powers of the Chair of the Working Group on Amendments (WGA) and Streamlining Mandate

An assessment of the de facto review of the Court's decision under Article 51(3) carried out by the ASP can be attributed to individual transgression, as discussed in section 2. To address this transgression, it is important to locate the forum where it originates. In this instance, this is the WGA, where substantive deliberations on matters of amendments, to the Rome Statute as well as the $\mathrm{RPE}$, take place. Therefore, analysing the format and structure of the WGA as a subsidiary organ of the ASP is of vital significance.

As identified in section 2, the 'transgression' referred to occurred by broadening the scope of deliberation through their individual statements within this forum. This section therefore proposes, the strengthening of the role of the Chairperson of Working Groups under the ASP framework. In this case, fortifying the role of the Chairperson of the WGA. This is in view of the importance of the role of chairpersons, facilitators, and coordinators in general, which can be immensely influential. Practice, as well as the drafting history of the Rome Statute and amendments thereto, depicts the significant role that these individuals play. This often involves introducing drafts that reconcile opposing views and facilitate adoption of universally agreed upon texts.

The proposal therefore, is to empower the Chairperson of the WGA to be able to pronounce that a statement made by an individual State goes beyond the scope of the mandate of the WGA. It also would enable the Chairperson to direct the members to take a decision, if necessary, through a vote.

113 See for e.g., Review Conference, Resolution RC/Res. 6, Annex III, Understandings Regarding the Amendments to the Rome Statute of the International Criminal Court on the Crime of Aggression, (2010) RC/11, at 22. 
This would entail the power to make a determination of whether the substance of the matter being introduced or discussed is in conformity with the mandate conferred on the WGA. This also implies the ability to place such determination on record, which is also of great significance. Essentially this would entail either empowering the Chairperson to interpret the mandate of the WGA in relation to the matter being brought forward by a State, or alternatively requiring them to consider such statement, and refer the matter to the ASP vis-à-vis the Bureau. The Bureau would then clarify through the various mechanisms and procedure available to it, whether this consideration is compatible with the mandate of the WGA. Thus ideally, in light of the nature of operations at the ASP, such procedure would need to be triggered by another statement made by a State Party to this effect.

While modifying the role of the Chairperson might address instances of individual transgression, there are certain issues that would first need to be dealt with. These include the role that the ASP Bureau would play, in relation to this proposed procedure as well as a clear deliberation of the extent of individual roles.

Most importantly, for either the President of the Bureau or the Chair of the WGA to insist that States adhere strictly to the deliberation of matters within the competence of the ASP, a clearer and more delineated mandate would have to be adopted. This is especially in the case for the WGA. While this might lead to a delay in the activities of the WGA, it would address the issue of individual transgression, as well as function as a mechanism to ensure greater compliance with the Statute and Rules thereunder.

\subsection{Addressing the Compliance of the ASP with the Rome Statute in Light of the Issue of Article 51(3)}

Apart from conducting a de facto review of the decision of the Court under Article 51(3), the manner in which the ASP dealt with the adoption of provisional Rule 165 raises another issue of significance in relation to the judicial function of the Court. This section deals with the impact of the inaction of the ASP, on the function of the Court. It also analyses the application of the proposed amendment to the role of the Chairperson of the WGA as suggested earlier.

Article 51(3) caters for the judges to provisionally adopt rules in urgent cases that are not catered for under the Rules. However, the provision unambiguously stipulates that such provisional rule shall apply until the adoption, amendment or rejection of the rule by the ASP at its next session. 
The ASP did not take a decision on the matter. Instead a Report stating that the matter will be continued to be deliberated within the forum of the WGA, was adopted. In other words, it could be said that the Asp decided not to exercise any of the options provided for, under Article 51(3) for the time being. This has not been provided for in the Rome Statute and is prima facie against the provisions of the Rome Statute.

This apparent non-compliance of the ASP with the Rome Statute significantly affects the function of the Court. This is because it has effectively left the applicability of the rule in question, Rule 165 , in a state of flux. There is an unquestionable uncertainty attached to the applicability of the new rule. This is especially profound in light of the nature of the rule, which reduces the number of judges in Article 70 cases and dis-applies several provisions of the Rome Statute itself to such cases. ${ }^{114}$ This is particularly relevant given the two Article 70 cases that are on the Court's docket at the moment. ${ }^{115}$

It is interesting to note however, that there does not appear to be a forum to address the non-compliance of the ASP with the Rome Statute. The ICC has not been conferred the ability to assess the compliance of its injugovin with the Rome Statute. ${ }^{116}$ The possibility of a referral to the ICJ, similar to one catered for disputes between States in relation to the interpretation of the Rome Statute cannot be completely ruled out. However, it is unlikely that this would materialize, especially in light of the jurisdictional requirements before the ICJ. The only method through which this could be addressed at the ICJ would be through a dispute arising between two or more States Parties in relation to the interpretation of the Statute, or through the form of an advisory opinion which has to be sought through 'organs of the United Nations or other specialized agencies.'117

114 ICC, Report on the Adoption by the Judges of Provisional Amendments to Rule 165, supra note 1.

115 Prosecutor v. Paul Gicheru and Philip Kipkoech Bett, Situation in the Republic of Kenya, Order Unsealing the Warrant of Arrest and Other Documents, Pre-Trial Chamber II, 10 September 2015, ICC-01/o9-01/15; Prosecutor v. Walter Osapiri Barasa, Situation in the Republic of Kenya, (Reclassified as Public) Warrant of Arrest for Walter Osapiri Barasa, Pre Trial Chamber II, 2 August 2013, ICC-01/o9-01/13.

116 In contrast, the ICJ has previously reviewed decisions by the GA and held that they were ultra vires K. Skubiszewski, 'The International Court of Justice and the Security Council', in V. Lowe and M. Fitzmaurice (eds.), Fifty Years of the International Court of Justice (Cambridge University Press, Cambridge, 2009) at 624.

117 UN Charter, Article 96. 
4.3.2 Applying the Proposed Mechanism to the issue of Article 51(3) and Possible Amendment to Article 51(3)

The suggested proposal involving the strengthening of the role of the Chairperson of the WGA can also be applied to this issue. This is because empowering the Chairperson to direct the WGA to take a decision, even if the decision is to reject the amendment on the lack of consensus, would ensure that a concrete proposal is put before the Bureau, which will accordingly adopt or vote on the matter. This will therefore ensure that a final decision is in fact taken on the matter by the plenary. Thus, preventing a situation where there is a state of uncertainty attached to the applicable legal procedure.

In the absence of a decision by the AsP in relation to the provisional rule adopted by the Court, there is no agreement of whether the provisional rule will apply or not. The application of the provisional rule itself, will undoubtedly be challenged by counsel for the defence if such a situation were to arise. Application of the Rule until the AsP takes a decision on the matter might also prove to be problematic. This is because the Rome Statute caters only for provisional adoption of rules by the Court. In a situation where there is no mechanism to ensure that the AsP takes a decision on the matter, the rule could arguably apply perpetually.

Therefore, the inaction of the AsP, by not deciding to adopt, amend or reject the provisional rule at its next session is not in consonance with the Rome Statute. The only way this could be dealt with is through an amendment to Article 51 (3) to provide for a situation where the AsP decides not to adopt, amend or reject the provisional rule. This would clarify the 'status' of such a rule. This could be done by incorporating the 'automatic rejection' theory within the text of the Statute as discussed under section 1.

An assessment of the relationship between the ICC and the ASP reveals the possibility of the ASP to step outside its mandate under the Rome Statute. This is highlighted in section 1 , through the situation concerning the adoption of provisional Rule 165 by the Court, and the failure of the ASP to adopt, amend or reject this provisional rule. This action of the ASP does not appear to have been catered for under the Rome Statute. Arguably, this affects the judicial function of the Court, upsetting the delicate balance between independence and accountability within the relationship between the ICC and its injugovin.

Section 2 concludes that the overreach detailed under section 1 can be attributed to individual transgression. The scope for individual transgression 
appears to arise through an overlap in competencies between the ICC and the ASP, owing to ambiguity in the procedural detail that governs the institutional regime of the Rome Statute. This allows the ASP to transgress through a de facto review of the decision of the Court under Article 51(3).

An evaluation of the merits and demerits of a possible review in section 3 showcases, that the latter outweigh the former. This is especially in view of the lack of legal basis for such review, as well as the absence of an appropriate forum for the same.

In light of the possibility of overreach by the ASP, an assessment of mechanisms available under the Rome Statute such as decision making through consensus, reveals that this is insufficient as an effective safeguard. Thus, the proposal for amending the role of the Chairperson of the WGA addresses this issue.

A holistic analysis of the response of the ASP to the provisional amendment to Rule 165 by the Court depicts that this adversely affects the independent judicial function of the Court. This is through the de facto review carried out by the ASP. More significantly, this has left the applicability of the rule in a state of flux. The application of the proposed strengthening of the role of the Chairperson of the WGA would arguably prevent both individual transgression by States, as well as ensure the compliance of the ASP with the Rome Statute in this respect.

Finally, in light of the situation created through the inaction of the ASP and the question of carrying out a review of the decisions of the Court, there appears to be a visible lacuna in the law. There is an absence of a forum to address disputes that might arise between the ICC and the ASP. An example of such a dispute is that of whether the question of the applicability of provisional Rule 165 falls within the ambit of 'judicial function' or not. There also appears to be no mechanism in place to ensure that the ASP complies with the Rome Statute. While this could have been intentional on the part of the States Parties to the Rome Statute, it threatens to affect the judicial function of the Court, as illustrated through the uncertainty shrouding the application of provisional Rule 165. This can be addressed through the proposal to strengthen the role of the Chairperson of the WGA but might finally have to be developed through an amendment of the Statute and the underlying regime itself.

It is important to acknowledge that international criminal justice and international adjudication in general, are important facets of the international legal order. It is equally quintessential to be cognizant of the machinery that facilitates such adjudication. Injugovins such as the ASP are an integral component of the effective functioning of international courts and tribunals. It is imperative therefore that these function efficiently, without transgressing 
into the domain of judicial function itself. Injugovins provide a much-needed platform for the accountability for these courts and tribunals. Simultaneously, these mechanisms of accountability liaise intermittently with several aspects of the international judicial function. The relationship between such accountability and indispensable judicial independence is intrinsically delicate. It is necessary therefore that there be adequate safeguards in place to maintain an optimal and beneficial balance between the two. 